\title{
Characterizing sampling and quality screening biases in infrared and microwave limb sounding
}

\author{
Luis F. Millán ${ }^{1}$, Nathaniel J. Livesey ${ }^{1}$, Michelle L. Santee ${ }^{1}$, and Thomas von Clarmann ${ }^{2}$ \\ ${ }^{1}$ Jet Propulsion Laboratory, California Institute of Technology, Pasadena, California, USA \\ ${ }^{2}$ Institut für Meteorologie und Klimaforschung, Karlsruhe Institute of Technology, Karlsruhe, Germany \\ Correspondence: Luis F. Millán (luis.f.millan@jpl.nasa.gov)
}

Received: 24 July 2017 - Discussion started: 6 September 2017

Revised: 24 February 2018 - Accepted: 5 March 2018 - Published: 27 March 2018

\begin{abstract}
This study investigates orbital sampling biases and evaluates the additional impact caused by data quality screening for the Michelson Interferometer for Passive Atmospheric Sounding (MIPAS) and the Aura Microwave Limb Sounder (MLS). MIPAS acts as a proxy for typical infrared limb emission sounders, while MLS acts as a proxy for microwave limb sounders. These biases were calculated for temperature and several trace gases by interpolating model fields to real sampling patterns and, additionally, screening those locations as directed by their corresponding quality criteria. Both instruments have dense uniform sampling patterns typical of limb emission sounders, producing almost identical sampling biases. However, there is a substantial difference between the number of locations discarded. MIPAS, as a mid-infrared instrument, is very sensitive to clouds, and measurements affected by them are thus rejected from the analysis. For example, in the tropics, the MIPAS yield is strongly affected by clouds, while MLS is mostly unaffected.

The results show that upper-tropospheric sampling biases in zonally averaged data, for both instruments, can be up to 10 to $30 \%$, depending on the species, and up to $3 \mathrm{~K}$ for temperature. For MIPAS, the sampling reduction due to quality screening worsens the biases, leading to values as large as 30 to $100 \%$ for the trace gases and expanding the $3 \mathrm{~K}$ bias region for temperature. This type of sampling bias is largely induced by the geophysical origins of the screening (e.g. clouds). Further, analysis of long-term time series reveals that these additional quality screening biases may affect the ability to accurately detect upper-tropospheric longterm changes using such data. In contrast, MLS data quality screening removes sufficiently few points that no additional bias is introduced, although its penetration is limited to the
\end{abstract}

upper troposphere, while MIPAS may cover well into the mid-troposphere in cloud-free scenarios. We emphasize that the results of this study refer only to the representativeness of the respective data, not to their intrinsic quality.

Copyright statement. The author's copyright for this publication is transferred to California Institute of Technology.

\section{Introduction}

Satellite limb sounders have provided a wealth of information for studies affecting climate, ozone layer stability, and air quality, as well as evaluation of reanalyses and chemistry climate models. Compared to ground-based instruments or aircraft field campaigns, satellite data provide continuous coverage over large areas (or even global scales, depending on their sampling), facilitating model evaluation on a large scale. Further, like many ground-based datasets, satellite missions such as the Atmospheric Chemistry Experiment Fourier Transform Spectrometer (ACE-FTS) (Bernath et al., 2005) and the Aura Microwave Limb Sounder (MLS) (Waters et al., 2006) have records that span more than a decade. In addition, data records constructed using several satellite instruments that span more than 3 decades (Froidevaux et al., 2015; Davis et al., 2016) provide the opportunity to study and evaluate long-term variability and trends. However, satellite observations sample the continuously changing atmosphere only at discrete locations and times, which can result in a biased depiction of the atmospheric state. 
Several studies have evaluated the impact of orbital sampling by comparing raw model fields against satellitesampled ones (e.g. McConnell and North, 1987; Bell and Kundu, 1996; Engelen et al., 2000; Luo et al., 2002; Brindley and Harries, 2003; Aghedo et al., 2011; Guan et al., 2013). For the limb sounding technique, Sofieva et al. (2014) estimated the sampling biases in zonal mean $\mathrm{O}_{3}$ profiles from six limb-viewing satellite instruments and proposed a simple parameterization to estimate them. Toohey et al. (2013) characterized the sampling bias for $\mathrm{H}_{2} \mathrm{O}$ and $\mathrm{O}_{3}$ for 16 satellite instruments, including limb scattering sounders, solar and stellar occultation instruments, and limb emission sounders. They concluded that coarse non-uniform sampling leads to non-negligible zonal mean biases, not only through nonuniform spatial sampling but mostly through non-uniform temporal sampling, that is, producing means using measurements that span less than the full period in question. Millán et al. (2016) studied the sampling bias for temperature and several trace gas species for a subset of the instruments used by Toohey et al. (2013) and investigated the impact of such biases upon stratospheric trend detection. They found that coarse non-uniform sampling patterns can induce significant errors in the magnitudes of trends inferred directly from monthly zonal means, necessitating analysis of considerably more years of data to conclusively detect a trend. In contrast, dense uniform sampling patterns accurately reproduce the magnitude of the trends, with the number of years of data required determined mostly by natural variability.

However, none of these studies have quantified the additional biases introduced through quality screening of the measurements. This study isolates and quantifies additional uncertainty in averaged data introduced by this screening. Many of the measurements discarded through quality screening have been affected by the presence clouds, which pose a substantial challenge to limb observations as the long limb path traverses hundreds of kilometres. The impact of such cloudy scenes depends on the measurement technique used. For example, instruments measuring microwave emission are unaffected by all but the largest particles in the thickest clouds. Limb measurements can also be screened out because of temperature gradients near the poles, whose impact varies depending on the retrieval scheme, i.e. one-dimensional versus tomographic, as well as how accurately the a priori or initial guess captures such gradients (e.g. Livesey and Read, 2000; Carlotti et al., 2001, 2006; Kiefer et al., 2010; Castelli et al., 2016).

This study examines the sampling bias and quantifies the impact of quality screening upon two limb viewing instruments, one using microwave emission (MLS) and the other one using infrared emission (the ENVISAT Michelson Interferometer for Passive Atmospheric Sounding - MIPAS). Both instruments have dense uniform sampling distributions, which should minimize the sampling biases; however, there is a substantial difference in the number of measurements rejected through quality screening for these techniques (see (a)

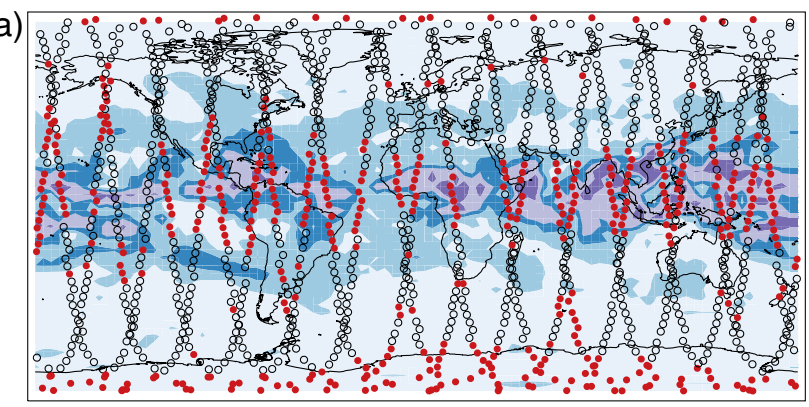

(b)

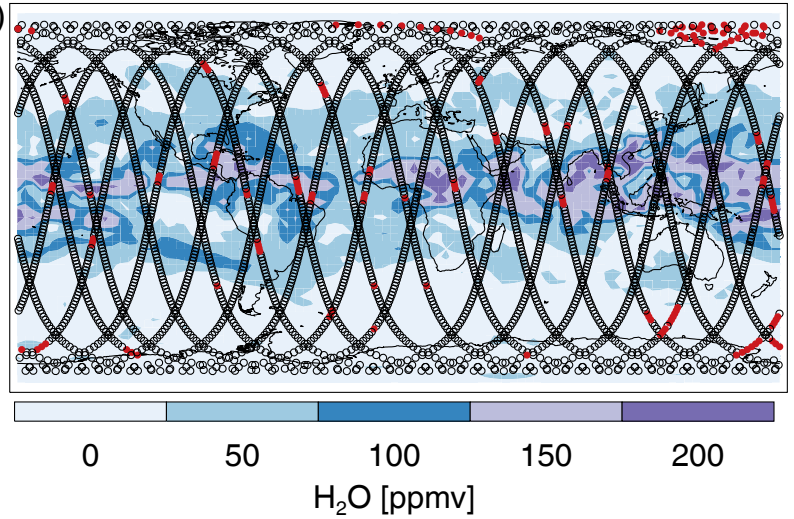

Figure 1. Typical MIPAS (a) and MLS (b) sampling overlaid on top of a modelled water vapour map (1 June 2005) at $200 \mathrm{hPa}$. Red dots show missed or failed retrievals: in the tropics, these are mostly due to clouds.

Fig. 1). The discarded profiles tend to cluster geophysically, leading to biases in analyses that are based on the remaining measurements. We emphasize that the results of this study refer only to the representativeness of the respective data, not to their intrinsic quality. Their quality has been extensively evaluated in numerous data characterization and validation papers (i.e. Pumphrey et al., 2007; Read et al., 2007; Santee et al., 2007; Schwartz et al., 2008; Stiller et al., 2012; Hegglin et al., 2013; Raspollini et al., 2013; Neu et al., 2014; Livesey et al., 2017; Sheese et al., 2017). Furthermore, their longterm stability has also been studied (i.e. Nair et al., 2012; Eckert et al., 2014; Hubert et al., 2016; Hurst et al., 2016).

\section{Data and methodology}

\subsection{Model fields}

CMAM30-SD (the Canadian Middle Atmosphere Model run in Specified Dynamics mode) is a coupled chemistry climate model nudged to the winds and temperatures of the ERA-Interim reanalysis. This nudging exploits the much better dynamics of the reanalysis to reliably predict the chemical fields. More information can be found in Scinocca et al. (2008); de Grandpré et al. (2000); McLandress et al. (2014). Extensive validation (de Grandpré et al., 2000; Hegglin and Shepherd, 2007; Melo et al., 2008; Jin et al., 2005, 2009) 
has shown that the free-running version of this model performs well against observations relevant to dynamics, transport, and chemistry. Comparisons against ACE-FTS and the Odin Optical Spectrograph and Infrared Imaging System (OSIRIS) have shown that CMAM30-SD has a good representation of stratospheric temperature, $\mathrm{H}_{2} \mathrm{O}, \mathrm{O}_{3}$, and $\mathrm{CH}_{4}$ in polar regions (Pendlebury et al., 2015). Further, CMAM30$\mathrm{SD}$ has been used to construct a long-term $\mathrm{H}_{2} \mathrm{O}$ record, acting as a transfer function between satellite observations (Hegglin et al., 2014), and it reproduces halogen-induced mid-latitude $\mathrm{O}_{3}$ depletion sufficiently well to be used in longterm $\mathrm{O}_{3}$ trend studies (Shepherd et al., 2014).

The CMAM30-SD version used in this study has a horizontal resolution of approximately $3.75^{\circ}$, that is, approximately $400 \mathrm{~km}$ (similar to the $\sim 500 \mathrm{~km}$ limb viewing path length). It has a lid at $0.0007 \mathrm{hPa}$ with 63 vertical levels whose spacing varies from $\sim 500 \mathrm{~m}$ in the lower troposphere to $\sim 3 \mathrm{~km}$ in the mesosphere. Here, we present results using the $\mathrm{H}_{2} \mathrm{O}, \mathrm{O}_{3}, \mathrm{CO}, \mathrm{HNO}_{3}$, and temperature CMAM30SD fields. Note that for this study it is not necessary for the model fields to be correct in absolute terms. CMAM30-SD is simply used as a representative evolving atmospheric state.

\subsection{Satellite instruments}

We analyse the impact of sampling and quality screening of the limb emission sounders MIPAS and MLS. MIPAS (Fischer et al., 2000, 2008) was launched in March 2002 on the European Space Agency Environment Satellite. MIPAS was a Fourier transform spectrometer conceived to record limb emission spectra. It covered the mid-infrared region from 685 to $2410 \mathrm{~cm}^{-1}$ in five spectral bands, allowing retrievals of temperature, pressure, and trace gases. MIPAS measured around 1350 vertical scans daily, providing global observations.

From July 2002 to March 2004, MIPAS operated in full resolution mode, with a spectral spacing of $0.025 \mathrm{~cm}^{-1}$; however, following persistent malfunctions with the interferometer slide mechanism, instrument operations were temporarily suspended. In January 2005 operations were resumed with MIPAS operating at a spectral spacing of $0.0625 \mathrm{~cm}^{-1}$. This mode of operation is known as optimum resolution, and it is characterized by finer vertical and horizontal sampling attained through the degraded spectral spacing. MIPAS took quasi-continuous measurements until April 2012, when the European Space Agency lost contact with ENVISAT.

In the optimum resolution operation, MIPAS has several measurement modes: the nominal mode, with 27 tangent heights from 6 to $70 \mathrm{~km}$; the middle atmosphere mode, with 29 tangent heights from 18 to $102 \mathrm{~km}$; and the upper atmosphere mode, with 35 tangent heights from 42 to $172 \mathrm{~km}$. The nominal mode covers the entire stratosphere, extending into both the upper troposphere and the lower mesosphere to study linkages between these atmospheric layers. In this study we use the geolocations of this measurement mode be- cause it covers around $80 \%$ of the measurement time (Fischer et al., 2008).

Several retrieval algorithms have been developed for the MIPAS spectra (e.g. Ridolfi et al., 2000; von Clarmann et al., 2003; von Clarmann et al., 2009; Hoffmann et al., 2005; Carlotti et al., 2006; Dudhia, 2017). Here we use the profiles generated by the Institute of Meteorology and Climate Research (IMK) in cooperation with the Instituto de Astrofísica de Andalucía (von Clarmann et al., 2009), in particular version 5. MIPAS IMK/IAA algorithm retrieves temperature and more than 30 species including $\mathrm{O}_{3}, \mathrm{H}_{2} \mathrm{O}, \mathrm{CO}, \mathrm{CFCs}$, and PAN, among many others. This retrieval algorithm uses a Tikhonov regularization; it is capable of handling deviations from local thermodynamic equilibrium, and it includes temperature horizontal gradients along the line of sight to prevent many retrievals from failing to converge, particularly near the boundary of the poles. Horizontal gradients are important because the line of sight extends around $1000 \mathrm{~km}$, crossing situations where the assumption of horizontal homogeneity (i.e. 1-D retrievals) is unrealistic. Several studies have discussed the advantages of including inhomogeneities along the line of sight for atmospheric retrievals (e.g. Livesey and Read, 2000; Carlotti et al., 2001, 2006; Kiefer et al., 2010; Castelli et al., 2016).

MLS (Waters et al., 2006) was launched in July 2004 on the Aura spacecraft. MLS measures limb millimetre and submillimetre atmospheric thermal emission in spectral regions near $118,191,240$, and $640 \mathrm{GHz}$ and $2.5 \mathrm{THz}$. These radiances are inverted using a 2-D tomographic optimal estimation algorithm (Livesey et al., 2006) that allows the retrieval of temperature and composition. MLS measures around 3500 vertical scans daily, providing near-global $\left(82^{\circ} \mathrm{S}\right.$ to $\left.82^{\circ} \mathrm{N}\right)$ observations.

To investigate the impact of sampling and quality screening, daily CMAM30-SD model fields were linearly interpolated to the actual latitude and longitude of the satellite measurements. For the MIPAS sampling pattern, for each calendar day of the year we identify the year with the most measurements obtained on that date. That is to say, for 1 January, we use the locations of 1 January for the year with the most measurement locations, and so on. This allows us to have a complete year of MIPAS measurements without interruptions due to MIPAS changing measurement modes. For MLS, we use 2008 as a representative year. To avoid differences attributed to diurnal cycles, all satellite measurements were assumed to be made at 12:00 UT on a given day, avoiding any interpolation in time. Further, we used the vertical grid of the CMAM30-SD fields; that is, the impact of the vertical resolution of the measurements is not taken into account. However, note that, in this case, both instruments have similar vertical resolutions in the upper troposphere-lower stratosphere (UTLS), varying overall from 3 to $4 \mathrm{~km}$.

We constructed three time series: one using the raw CMAM30-SD fields; another using all the measurement locations available; and lastly one using only the measurement 


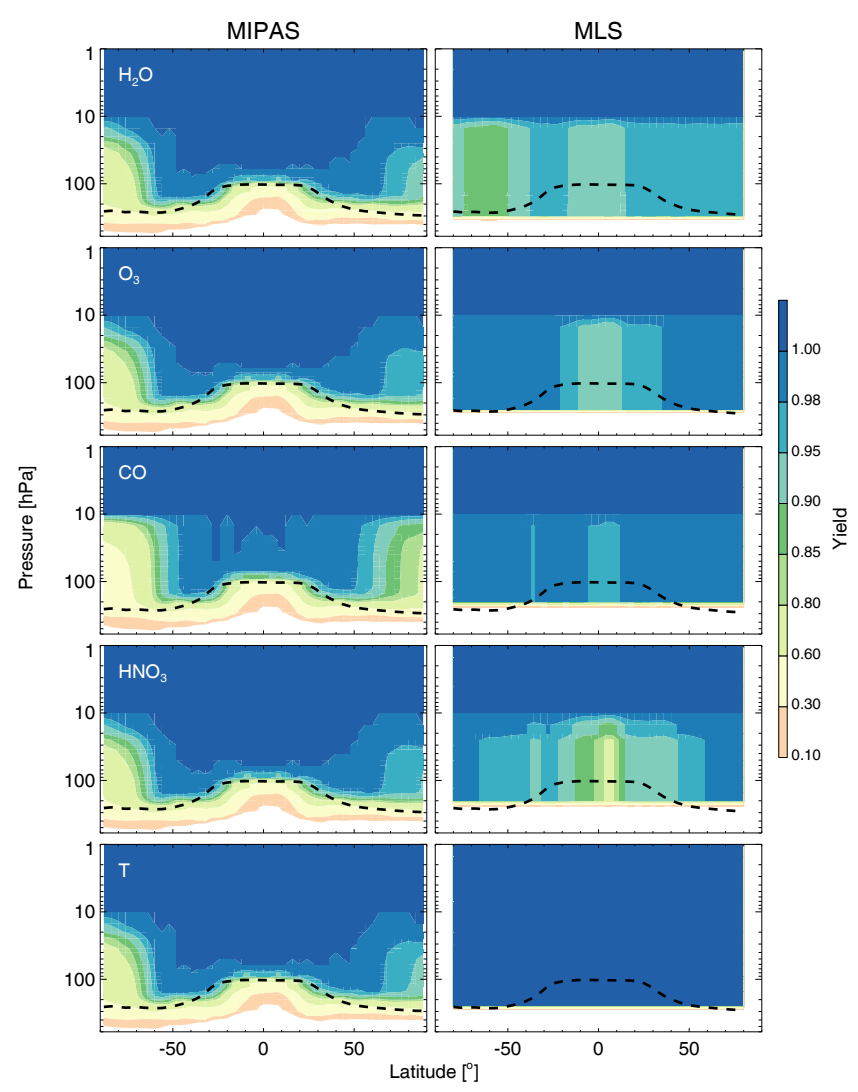

Figure 2. MIPAS and MLS zonal mean yield $\left(N_{\mathrm{QS}} / N_{\mathrm{A}}\right.$, where $N_{\mathrm{A}}$ is the number of measurements available and $N_{\mathrm{QS}}$ is the number of measurements left after applying the quality screening criteria) for $\mathrm{H}_{2} \mathrm{O}, \mathrm{O}_{3}, \mathrm{CO}, \mathrm{HNO}_{3}$, and temperature for 2005 , that is, sampling the modelled 2005 year with the sampling patterns as explained in the text. Note the non-linear colour scale. The dashed black lines show the mean 2005 thermal tropopause derived from the Modern Era Retrospective Analysis for Research and Application-2 (MERRA2) fields (Bosilovich et al., 2015). This tropopause information was obtained from the derived meteorological products as described by Manney et al. (2007, 2011).

locations remaining after the quality screening recommended for each instrument was applied, in other words, after those points flagged as bad values in the actual data were eliminated. The screening procedure applied to MIPAS data is as follows: we neglect profile points where the diagonal element of the averaging kernel is less than 0.03 - to avoid retrievals influenced by the a priori - and discard points where the visibility flag was set to zero - which indicates that MIPAS has not seen the atmosphere at those particular altitudes. The screening procedure applied to MLS data follows the guidelines detailed by Livesey et al. (2017): we only use data within the specified pressure ranges; we neglect profile points for which the precision is negative (which indicates that the retrievals are influenced by the a priori); we avoid profiles for which the "status" field is an odd number (which indicates operational abnormalities or problems with the re- trievals); and we only use profiles for which the "quality" and "convergence" fields are within the specified thresholds. The "quality" field describes the degree to which the measured radiances have been fitted by the retrieval algorithm and the "convergence" field is a ratio of the fit achieved at the end of the retrieval process to the value predicted at the previous step.

Figure 1 shows typical daily MIPAS and MLS geolocations overlaid on top of a modelled water vapour map. Both instruments have dense coverage that, as noted by Toohey et al. (2013), is relatively uniform with latitude and time. Figure 1 also displays those geolocations for which the retrieved values are not recommended for scientific studies; that is, they are screened out by the quality criteria. As shown, these failed or in many cases skipped retrievals cluster in the tropics or near the poles. Overall, in the tropics, these missing retrievals are due to clouds. Near the poles, the retrieval failures are presumably due to temperature horizontal gradients and, in the case of MIPAS, also due to the presence of polar stratospheric clouds. The substantial difference between the number of failed or missing retrievals in the tropics for MIPAS and MLS is the main motivation for this study.

To quantify this further, Fig. 2 displays the yield given by

$Y=\frac{N_{\mathrm{QS}}}{N_{\mathrm{A}}}$,

where $N_{\mathrm{A}}$ is the number of measurements available and $N_{\mathrm{QS}}$ is the number of measurements left after applying the quality screening criteria at each latitude and each pressure level. Again, MIPAS low yield values accumulate in the tropics and near the poles. Overall, MIPAS yields drop below $60 \%$ near the South Pole at pressures greater than $\sim 20 \mathrm{hPa}$ and below $30 \%$ in the tropics at pressures greater than $100 \mathrm{hPa}$. In contrast, in general MLS yield values are better than $90 \%$, although the measurements do not extend below the upper troposphere. The two exceptions are the yield values for $\mathrm{H}_{2} \mathrm{O}$ near the South Pole, which drop below $90 \%$, and $\mathrm{HNO}_{3}$ near the Equator, which drop to $60 \%$. Note that MIPAS yield values drop below $10 \%$ well into the troposphere.

\section{Induced sampling and quality screening biases}

Following Millán et al. (2016), we evaluate the sampling biases as well as the quality screening biases associated with constructing monthly zonal means using the raw CMAM30SD fields, $Z_{\mathrm{R}}$, versus those using the satellite-sampled measurements, $Z_{\mathrm{A}}$, or only those passing the quality screening criteria, $Z_{\mathrm{QS}}$. The difference between $Z_{\mathrm{A}}$ or $Z_{\mathrm{QS}}$ and $Z_{\mathrm{R}}$ gives the sampling or the quality-screening-induced bias, respectively. For each instrument and for each month throughout 1 year, we computed these biases as a function of latitude and pressure. Note that the quality screening bias is the sampling bias plus the additional impact of screening out more locations and, hence, reducing the sampling frequency. 


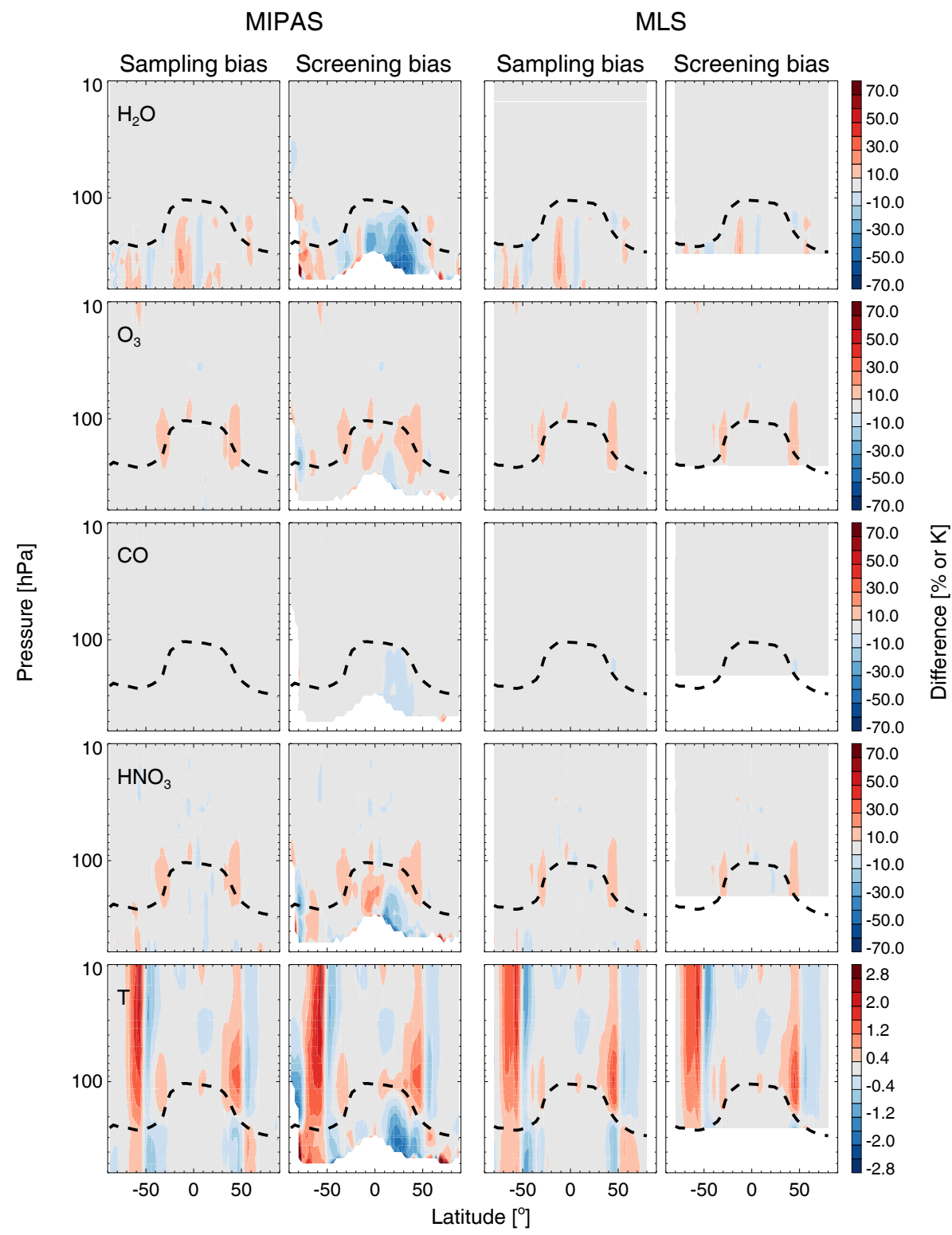

Figure 3. June 2005 sampling and quality screening biases as a function of latitude and pressure for $\mathrm{H}_{2} \mathrm{O}, \mathrm{O}_{3}, \mathrm{CO}, \mathrm{HNO}_{3}$, and temperature as measured using MIPAS and MLS. White regions denote a lack of measurements. The dashed black lines show the mean June 2005 thermal tropopause derived from MERRA2.

Figure 3 shows examples of the sampling and screening biases for June 2005. Percentage biases are shown for the trace gases to cope with their large vertical variability. MIPAS and MLS sampling biases are practically identical. For the trace gases, sampling biases are larger in the upper troposphere, where the variability is larger, while the temperature sampling biases are larger near the edges of the polar regions, where there are substantial temperature gradients. The impact of the MIPAS quality screening is evident in the tropics (in particular near $20^{\circ} \mathrm{N}$ ), where the yield values are expected to be greatly affected (see Fig. 2) by clouds. In this region, on top of the sampling biases, all parameters studied display an underestimation, for example, up to $-50 \%$ for $\mathrm{H}_{2} \mathrm{O}$. Although this resembles the expected dry bias in clearsky tropospheric infrared measurements (e.g. Sohn et al., 2006; Yue et al., 2013) - that is, the fact that infrared instruments cannot measure cloudy regions where $\mathrm{H}_{2} \mathrm{O}$ is high, resulting in a dry bias - the biases shown here are due to a combination of two factors: (1) high $\mathrm{H}_{2} \mathrm{O}$ values associated with deep convection (the screened-out locations might not necessarily be cloudy in the model fields but they are for the most part in the tropics, in regions of high $\mathrm{H}_{2} \mathrm{O}$ values; see Fig. 1 for an example) and (2) due to the reduced sampling frequencies. Note that these two points are also applicable to 


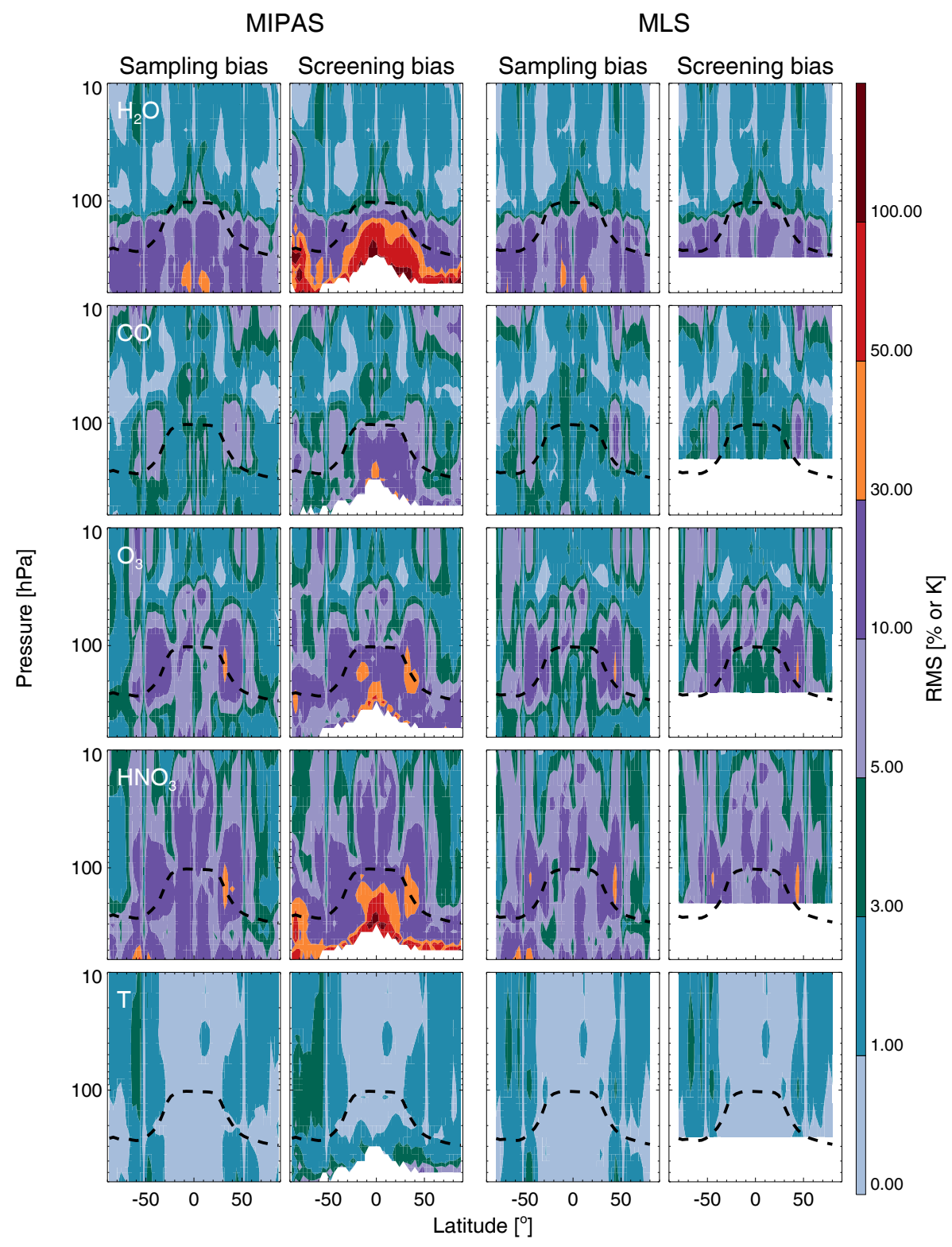

Figure 4. Root-mean-square sampling and quality screening biases for 2005 as a function of latitude and pressure for $\mathrm{H}_{2} \mathrm{O}, \mathrm{O}_{3}, \mathrm{CO}, \mathrm{HNO}_{3}$, and temperature as measured using typical MIPAS and MLS data coverage. The dashed black lines show the mean 2005 thermal tropopause derived from MERRA2.

other parameters; that is, the quality screening biases shown here are not an indication of the relationship between trace gas (or temperature) and deep convection. In contrast to those of MIPAS, except for the reduced vertical ranges, MLS sampling biases are unaffected by data quality screening.

We note that the cloud screening procedure of the IMK/IAA algorithm is conservative (i.e. it rejects more profiles) with respect to those of other MIPAS processors (Spang et al., 2012). On the face of it, it appears that this causes an unnecessarily large sampling bias which could be avoided by using a less restrictive cloud screening threshold value. The purpose of a conservative cloud screening procedure is to guarantee that the measurements passing the cloud screening are indeed unaffected by any cloud signal in the spectra. Cloud signals can lead to systematic retrieval errors, which are correlated to the state of the atmosphere; hence, the sampling biases would merely be replaced by retrieval biases. The latter, we think, is worse, because then both the parent data and the zonal averages would be affected, while with a conservative screening only the averages are affected but not the parent data that survive the screening.

To summarize the potential sampling and quality screening biases, Fig. 4 shows their root mean square (RMS) computed over 1 year's worth of data. Again, the MIPAS and 

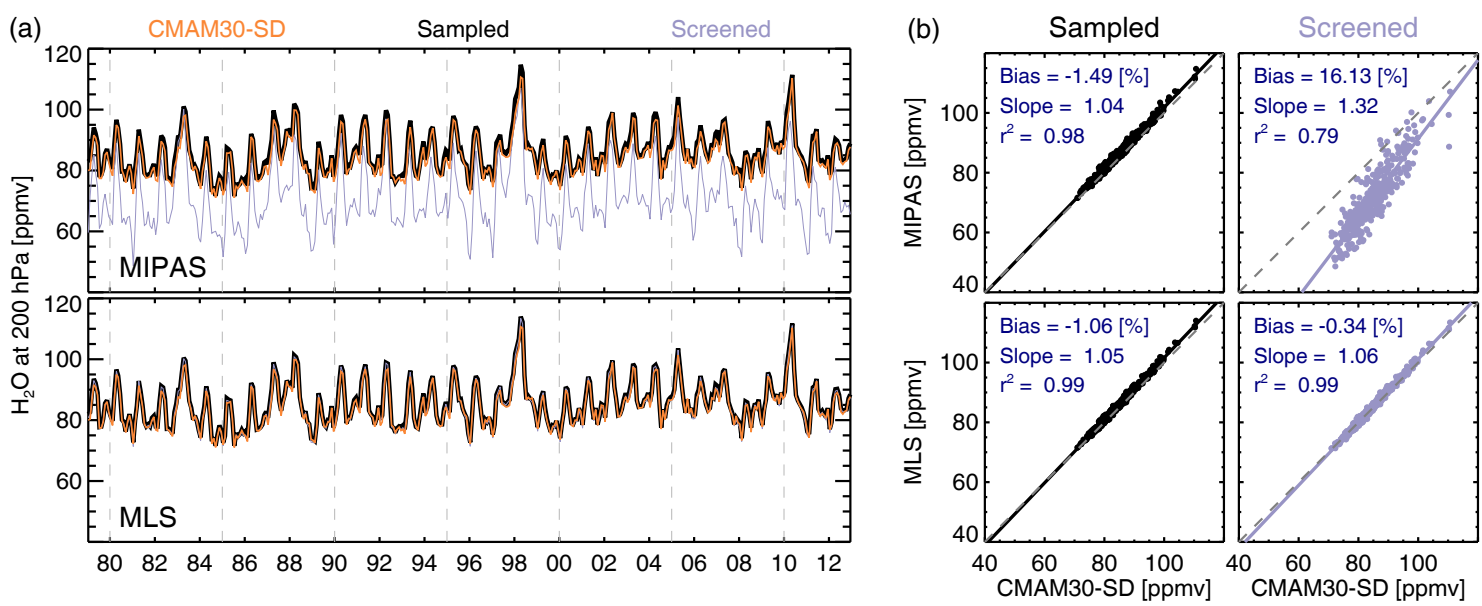

Figure 5. (a) Time series of $20^{\circ} \mathrm{S}-20^{\circ} \mathrm{N} \mathrm{H}_{2} \mathrm{O}$ at $200 \mathrm{hPa}$ for the raw CMAM30-SD fields (orange lines), the full satellite-sampled fields (black lines), and only those points passing the quality screening criteria (thin purple lines) for MIPAS and MLS. (b) Scatter plots between these time series. The dashed gray lines are the $1: 1$ line, and the solid lines are the linear best fits, whose slopes are given. Also, the coefficient of determination, $r^{2}$, and the bias are shown.

MLS RMS sampling biases are almost identical: $\mathrm{H}_{2} \mathrm{O}$ displays a bias of up to $30 \%$ at pressures greater than $\sim 150 \mathrm{hPa}$; $\mathrm{CO}, \mathrm{O}_{3}$, and $\mathrm{HNO}_{3}$ show biases (up to $30 \%$ for $\mathrm{O}_{3}$ and $\mathrm{HNO}_{3}$ ) near mid-latitudes (around $40^{\circ} \mathrm{S}$ and $40^{\circ} \mathrm{N}$ ), where there are sharp trace gas gradients and variability due to tropopause folding; and temperature displays a bias as large as $3 \mathrm{~K}$ near the polar edges.

The impact of MIPAS quality screening is especially evident in $\mathrm{H}_{2} \mathrm{O}$ and $\mathrm{HNO}_{3}$, which have potential biases as large as $100 \%$, but quality screening also affects the rest of the parameters: $\mathrm{CO}$ and $\mathrm{O}_{3}$ biases approach $30 \%$ in the tropics, while the region with $3 \mathrm{~K}$ temperature bias expands near the South Pole. As before, except for the reduced vertical ranges, the impact of the MLS quality screening is negligible; that is, the screening biases are almost identical to the sampling biases.

To exemplify the impact of these quality screening biases, Fig. 5 (left) shows time series (1979-2012) of $20^{\circ} \mathrm{S}$ to $20^{\circ} \mathrm{N} \mathrm{H}_{2} \mathrm{O}$ at $200 \mathrm{hPa}$ using the raw CMAM30-SD fields, the full satellite-sampled fields and only those points passing the screening criteria. All time series show the expected features, with an annual cycle related to the seasonality of the cold point tropopause temperature. The MIPAS time series constructed using the full satellite-sampled fields is almost identical to the one constructed using the raw CMAM30-SD field. However, as suggested by the screening bias shown in Fig. 4, the MIPAS time series using the quality screening displays a substantial dry bias. In contrast, no evidence of such a bias is seen in the MLS time series; that is, both the time series constructed using the full satellite-sampled field and that based on only those points passing the screening criteria are almost identical to the CMAM30-SD one.

Figure 5 (right) shows the area-weighted scatter between these time series. MIPAS sampling scatter, that is, the scat- ter between MIPAS when using all available measurements and the raw CMAM30-SD fields, is small and their correlation tight, with a bias better than $-1.5 \%$, a slope of $\sim 1.05$, and a coefficient of determination of 0.98 . The contrast with the MIPAS-screened scatter is dramatic in this particular latitude-pressure region; it displays considerably more scatter and, as in the time series (Fig. 5, left), a discernible bias. Quantitatively, MIPAS-screened data display a bias of $16.13 \%$, a slope of 1.32 , and a coefficient of determination of $\sim 0.8$ (which implies that $20 \%$ of the total variation cannot be explained). MLS sampling and screened scatter plots are almost the same.

To explore this further, Fig. 6 shows these metrics versus pressure using different latitude bands for the MIPAS sampling scatter. As shown, the coefficients of determination as well as the slopes are close to one and the biases close to zero in most cases. The most notable exceptions are the biases between 20 and $45^{\circ}$ (either north or south) for $\mathrm{O}_{3}$ and $\mathrm{HNO}_{3}$, which can be up to $-10 \%$. In these regions, Figs. 3 and 4 indicate biases due to the sharp trace gas gradients associated with tropopause folding. Note that both the MLS sampling and the MLS-screened scatter are almost identical to the MIPAS sampling scatter and, hence, are not shown.

The MIPAS-screened scatter results are shown in Fig. 7. The largest impact can be found in the tropics (the $20^{\circ} \mathrm{S}$ $20^{\circ} \mathrm{N}$ latitude band) at pressures greater than $100 \mathrm{hPa}$. Here, the coefficients of determination, the biases and the slopes are severely degraded. The coefficients of determination rapidly decrease, especially for $\mathrm{H}_{2} \mathrm{O}, \mathrm{O}_{3}$ and $\mathrm{HNO}_{3}$, whose values are as low as 0.5 at $200 \mathrm{hPa}$ and worsen further at lower altitudes. The biases for $\mathrm{O}_{3}$ and $\mathrm{HNO}_{3}$ oscillate between -10 and $10 \%$ and can be as large as $40 \%$ for $\mathrm{H}_{2} \mathrm{O}$. Lastly, all the slopes vary from 0.5 to 1.5 , depending on pressure level. These poor metrics suggest that any 


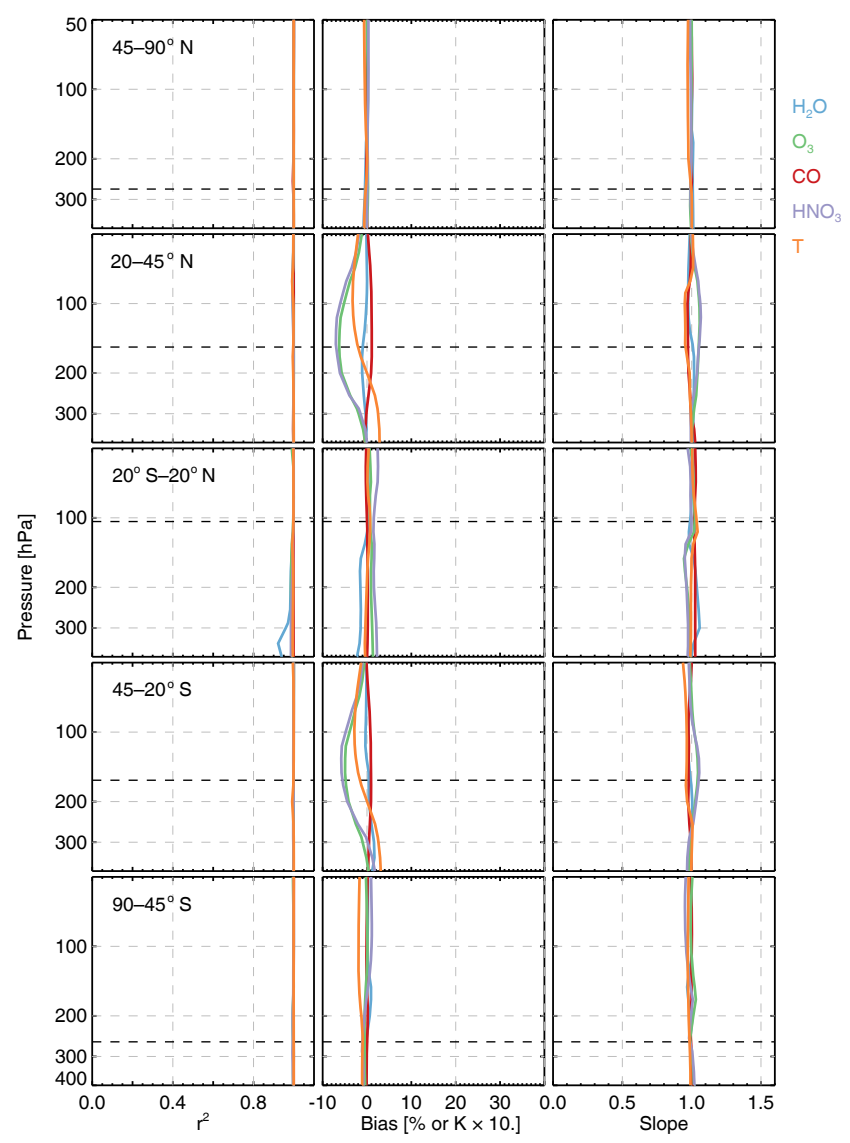

Figure 6. Vertical profiles of the coefficient of determination, the bias, and the linear fit slope for different latitude bands for the MIPAS vs CMAM30-SD scatter using the full satellite-sampled fields. Note that for clarity the temperature bias is shown as $\mathrm{K} \times 10$. Blue, green, red, purple, and orange lines represent $\mathrm{H}_{2} \mathrm{O}, \mathrm{O}_{3}, \mathrm{CO}, \mathrm{HNO}_{3}$, and temperature metrics. The dashed black lines show the mean 2005 thermal tropopause derived from MERRA2 for the particular latitude bands.

trends derived at these pressure levels might also be impacted by quality-screening-induced biases. As an example, Fig. 8 shows the $\mathrm{H}_{2} \mathrm{O}$ and $\mathrm{O}_{3}$ trends in the tropics computed using monthly zonal mean deseasonalized anomalies of the raw model fields, as well as using all the available satellitesampled measurement locations and only those passing the screening criteria in the tropics. As shown, when all available measurement locations are used, the MIPAS and MLS sampling allows accurate derivation of trends, with values matching those calculated from the raw model fields almost exactly. However, when only those measurements passing the screening criteria are used, both instruments have limitations: MIPAS trends are impacted because of the large percentage of measurements screened out below $100 \mathrm{hPa}$, which introduces non-negligible artefacts (for example, $0.8 \%$ decade $^{-1}$ for $\mathrm{H}_{2} \mathrm{O}$ at $200 \mathrm{hPa}$ versus $1.8 \%$ decade $^{-1}$ when all available measurements are used); MLS trends are impacted because

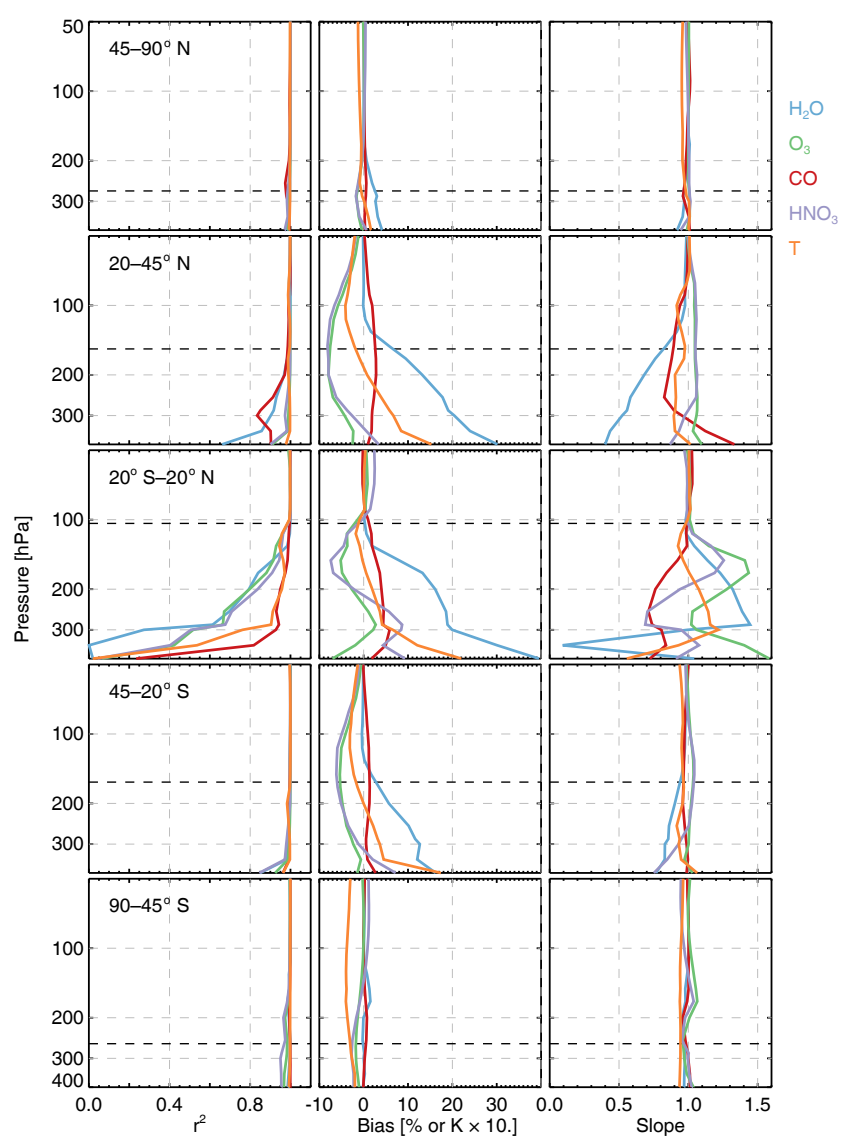

Figure 7. As in Fig. 6 but using only the profiles that passed the quality screening.

of the reduced vertical resolution, which limits its usefulness to the upper troposphere and above. Note that the impact of quality screening on MIPAS trends can be mitigated by using a regression model similar to the ones used by Bodeker et al. (2013) and Damadeo et al. (2014). These models have been shown to mitigate the effects of the non-uniform temporal, spatial, and diurnal sampling of solar occultation satellite measurements. Furthermore, a more robust trend analysis that includes the influence of dynamical variables, such as the quasi-biennial oscillation and El Niño-Southern Oscillation, will help reduce the number of years required to statistically detect such trends. In addition, MIPAS trend analysis can be restricted to regions less affected by deep convection (for example, the mid-tropical Pacific) to minimize the quality screening effects.

The estimated number of years required to definitively detect these trends is also shown in Fig. 8. These estimates were computed assuming a trend model similar to the one described by Tiao et al. (1990), Weatherhead et al. (1998), and Millán et al. (2016), with a seasonal mean component represented by the monthly climatological means. As shown, with the MIPAS-screened fields additional years are required for robust trend detection (up to a total of $\sim 120$ years for 


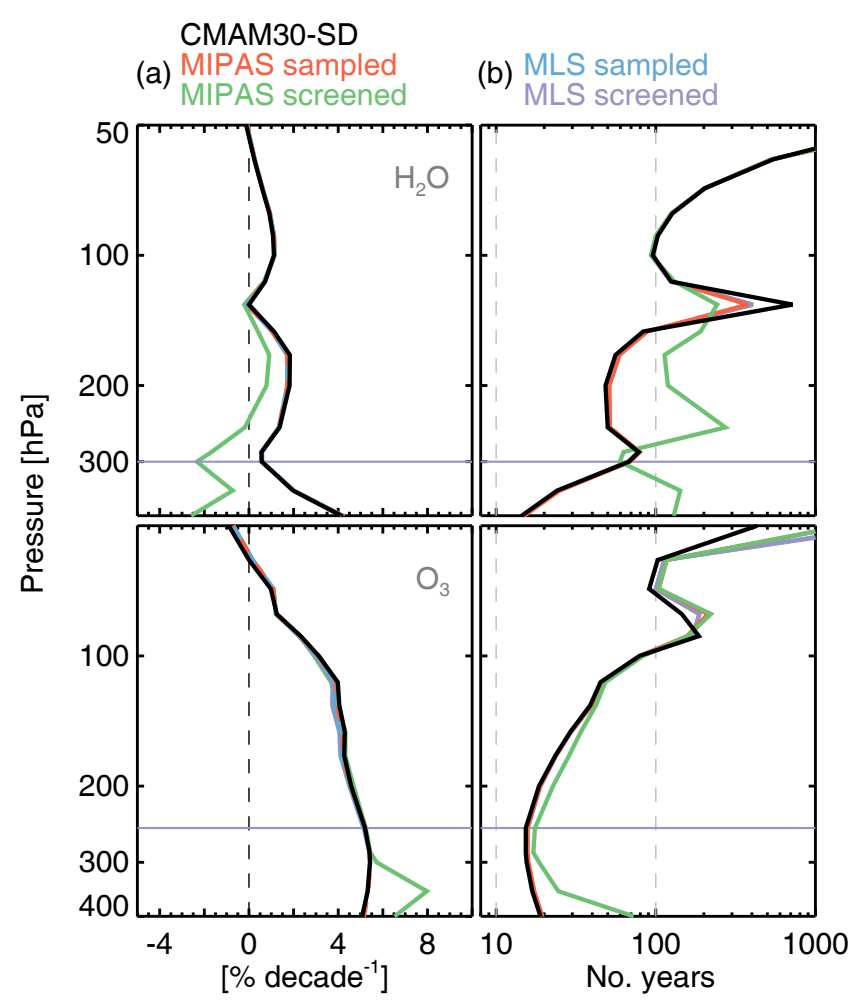

Figure 8. (a) $\mathrm{H}_{2} \mathrm{O}$ and $\mathrm{O}_{3}$ trends computed based on monthly zonal mean deseasonalized anomalies for the tropics $\left(20^{\circ} \mathrm{S}\right.$ to $\left.20^{\circ} \mathrm{N}\right)$ using the raw model fields, all the available satellite measurements (MIPAS or MLS sampled) and only those measurements passing the screening criteria (MIPAS or MLS screened). Note that for $\mathrm{O}_{3}$, we only use data starting from 2000 to capture the expected period of $\mathrm{O}_{3}$ recovery. A purple line indicates the bottom (largest pressure) of the recommended range of the MLS retrievals. (b) Number of years required to detect such trends.

$\mathrm{H}_{2} \mathrm{O}$ and up to $\sim 25$ years for $\mathrm{O}_{3}$ at $200 \mathrm{hPa}$ versus 50 years and 18 years, respectively, when all available measurements are used).

Similar analyses were performed for other latitude bands. Although the magnitude of the trends derived when using the MIPAS-screened measurement locations was also impacted in these cases, no significant difference was found in the number of years required to detect such trends. In addition, no significant artefacts were found for $\mathrm{HNO}_{3}, \mathrm{CO}$, or temperature for either the trend magnitude or the number of years required to detect such trends. Note that, when using real data, the effect of instrument noise upon trends will be negligible due to the vast number of MIPAS or MLS measurements associated with each monthly latitude bin. Drifts and long-term stability issues on these datasets (i.e. Eckert et al., 2014; Hubert et al., 2016; Hurst et al., 2016) will have to be corrected.

\section{Summary and conclusions}

This study explored the implications of sampling in the UTLS for two satellite instruments, MIPAS and MLS, for $\mathrm{H}_{2} \mathrm{O}, \mathrm{O}_{3}, \mathrm{CO}, \mathrm{HNO}_{3}$, and temperature. We quantify sampling biases by interpolating CMAM30-SD fields, used as a proxy for the atmospheric state, to the measurement locations and computing monthly means. Both of these instruments have dense uniform sampling, with around 1350 points spread globally for MIPAS and around 3500 spread from $82^{\circ} \mathrm{S}$ to $82^{\circ} \mathrm{N}$ for MLS, resulting in almost identical sampling biases for the two instruments. For the trace gases, the largest sampling biases are found in the upper troposphere, where there is more natural variability: $\mathrm{H}_{2} \mathrm{O}$ displays a bias of up to $30 \%$, while $\mathrm{CO}, \mathrm{O}_{3}$, and $\mathrm{HNO}_{3}$ show biases near mid-latitudes of up to $10 \%$ for $\mathrm{CO}$ or $30 \%$ for $\mathrm{O}_{3}$ and $\mathrm{HNO}_{3}$ due to sharp trace gas gradients and variability arising from tropopause folding. The temperature sampling bias is negligible (less than $1 \mathrm{~K}$ ), except near the polar edges, where the bias can be as large as $3 \mathrm{~K}$, presumably due to horizontal temperature gradients.

Besides the orbital sampling biases, this study also evaluated the impact of quality screening, which further reduces the sampling frequency. In the tropics (see Fig. 2), MIPAS is substantially impacted by clouds, as they act as grey bodies with high opacity, greatly altering the radiances below the cloud top. Cloud effects are evident, with $\mathrm{H}_{2} \mathrm{O}$ and $\mathrm{HNO}_{3}$ biases up to $100 \%$ and $\mathrm{CO}$ and $\mathrm{O}_{3}$ biases up to $30 \%$. In contrast, because of their longer wavelengths, MLS measurements are unaffected by all but the thickest clouds, negligibly impacting the sampling frequency. However, continuum absorption in the microwave suppresses signals from the middle and lower troposphere in a limb viewing geometry, limiting the MLS vertical range to the upper troposphere and above, while MIPAS may cover well into the mid-troposphere in cloud-free scenes.

Analysis of scatter plots of time series constructed using the raw model fields versus those using all the available measurement locations (either for MIPAS or MLS) reveals that at most pressure levels and most latitude bands, the coefficient of determination and the slope of the fits are close to one, while the biases are close to zero. However, when only those measurements passing the screening criteria are used, MIPAS upper-tropospheric measurements are severely impacted in some regions. In the tropics, the coefficients of determination rapidly decrease, especially for $\mathrm{H}_{2} \mathrm{O}, \mathrm{O}_{3}$, and $\mathrm{HNO}_{3}$, from $\sim 1$ at $100 \mathrm{hPa}$ to as low as 0.5 at $200 \mathrm{hPa}$, and they worsen further at lower altitudes. The biases for $\mathrm{O}_{3}$ and $\mathrm{HNO}_{3}$ oscillate between -10 and $10 \%$ and can be as large as $40 \%$ for $\mathrm{H}_{2} \mathrm{O}$. Lastly, all the slopes vary from 0.5 to 1.5 , depending on pressure level. These biases affect trends derived from these measurements using a simple regression upon monthly zonal mean data substantially affected by clouds. Further, the number of years required to detect such trends may increase due to the extra noise added to the time series 
by screening out measurements. Note that although these results were derived for MIPAS, they are applicable to other instruments with dense sampling but for which quality screening (e.g. for clouds) severely impacts their yield.

Data availability. The datasets used in this study are publicly available: CMAM30-SD fields can be found in the Canadian Centre for Climate Modelling and Analysis web page (http://www.cccma.ec. gc.ca/data/cmam/output/CMAM/CMAM30-SD/index.shtml, Government of Canada, 2017), MLS data can be found in the NASA Goddard Space Flight Center Earth Sciences Data and Information Services Center (https://mirador.gsfc.nasa.gov/cgi-bin/ mirador/homepageAlt.pl?keyword=MLS, last access: 1 May 2017), and MIPAS data can be found in the Karlsruhe Institute of Technology web page (https://www.imk-asf.kit.edu/english/308.php, Karlsruhe Institute of Technology, 2017).

Competing interests. The authors declare that they have no conflict of interest.

Acknowledgements. Work at the Jet Propulsion Laboratory, California Institute of Technology, was done under contract with the National Aeronautics and Space Administration. We thank David Plummer of Environment Canada for his assistance in obtaining the CMAM30-SD dataset. We thank the reviewers for their useful comments. Government sponsorship acknowledged.

Edited by: Michael Pitts

Reviewed by: three anonymous referees

\section{References}

Aghedo, A. M., Bowman, K. W., Shindell, D. T., and Faluvegi, G.: The impact of orbital sampling, monthly averaging and vertical resolution on climate chemistry model evaluation with satellite observations, Atmos. Chem. Phys., 11, 6493-6514, https://doi.org/10.5194/acp-11-6493-2011, 2011.

Bell, T. L. and Kundu, P. K.: A Study of the Sampling Error in Satellite Rainfall Estimates Using Optimal Averaging of Data and a Stochastic Model, J. Climate, 9, 1251-1268, https://doi.org/10.1175/15200442(1996)009<1251:asotse>2.0.co;2, 1996.

Bernath, P. F., McElroy, C. T., Abrams, M. C., Boone, C. D., Butler, M., Camy-Peyret, C., Carleer, M., Clerbaux, C., Coheur, P.-F., Colin, R., DeCola, P., DeMazière, M., Drummond, J. R., Dufour, D., Evans, W. F. J., Fast, H., Fussen, D., Gilbert, K., Jennings, D. E., Llewellyn, E. J., Lowe, R. P., Mahieu, E., McConnell, J. C., McHugh, M., McLeod, S. D., Michaud, R., Midwinter, C., Nassar, R., Nichitiu, F., Nowlan, C., Rinsland, C. P., Rochon, Y. J., Rowlands, N., Semeniuk, K., Simon, P., Skelton, R., Sloan, J. J., Soucy, M.-A., Strong, K., Tremblay, P., Turnbull, D., Walker, K. A., Walkty, I., Wardle, D. A., Wehrle, V., Zander, R., and Zou, J.: Atmospheric Chemistry Experiment
(ACE): Mission overview, Geophys. Res. Lett., 32, L15S01, https://doi.org/10.1029/2005g1022386, 2005.

Bodeker, G. E., Hassler, B., Young, P. J., and Portmann, R. W.: A vertically resolved, global, gap-free ozone database for assessing or constraining global climate model simulations, Earth Syst. Sci. Data, 5, 31-43, https://doi.org/10.5194/essd-5-312013, 2013.

Bosilovich, M., Akella, S., Coy, L., Cullather, R., Draper, C., Gelaro, R., Kovach, R., Liu, Q., Molod, A., Norris, P., Wargan, K., Chao, W., Reichle, R., Takacs, L., Vikhliaev, Y., Bloom, S., Collow, A., Firth, S., Labow, G., Partyka, G., Pawson, S., Reale, O., Schubert, S. D., and Suarez, M.: MERRA-2: Initial evaluation of the climate, NASA Tech. Rep Series on Global Modeling and Data Assimilation, 43, 2015.

Brindley, H. E. and Harries, J. E.: Observations of the Infrared Outgoing Spectrum of the Earth from Space: The Effects of Temporal and Spatial Sampling, J. Climate, 16, 3820-3833, https://doi.org/10.1175/15200442(2003)016<3820:ootios>2.0.co;2, 2003.

Carlotti, M., Dinelli, B. M., Raspollini, P., and Ridolfi, M.: Geo-fit approach to the analysis of limb-scanning satellite measurements, Appl. Opt., 40, 1872-1885, https://doi.org/10.1364/AO.40.001872, 2001.

Carlotti, M., Brizzi, G., Papandrea, E., Prevedelli, M., Ridolfi, M., Dinelli, B. M., and Magnani, L.: GMTR: Two-dimensional geo-fit multitarget retrieval model for Michelson Interferometer for Passive Atmospheric Sounding/Environmental Satellite observations, Appl. Opt., 45, 716-727, https://doi.org/10.1364/ao.45.000716, 2006.

Castelli, E., Ridolfi, M., Carlotti, M., Sinnhuber, B.-M., Kirner, O., Kiefer, M., and Dinelli, B. M.: Errors induced by different approximations in handling horizontal atmospheric inhomogeneities in MIPAS/ENVISAT retrievals, Atmos. Meas. Tech., 9, 5499-5508, https://doi.org/10.5194/amt-9-5499-2016, 2016.

Damadeo, R. P., Zawodny, J. M., and Thomason, L. W.: Reevaluation of stratospheric ozone trends from SAGE II data using a simultaneous temporal and spatial analysis, Atmos. Chem. Phys., 14, 13455-13470, https://doi.org/10.5194/acp-14-134552014, 2014.

Davis, S. M., Rosenlof, K. H., Hassler, B., Hurst, D. F., Read, W. G., Vömel, H., Selkirk, H., Fujiwara, M., and Damadeo, R.: The Stratospheric Water and Ozone Satellite Homogenized (SWOOSH) database: a long-term database for climate studies, Earth Syst. Sci. Data, 8, 461-490, https://doi.org/10.5194/essd8-461-2016, 2016.

de Grandpré, J., Beagley, S. R., Fomichev, V. I., Griffioen, E., McConnell, J. C., Medvedev, A. S., and Shepherd, T. G.: Ozone climatology using interactive chemistry: Results from the Canadian Middle Atmosphere Model, J. Geophys. Res.-Atmos., 105, 26475-26491, https://doi.org/10.1029/2000JD900427, 2000.

Dudhia, A.: MIPAS Orbital Retrieval using Sequential Estimation, available at: http://eodg.atm.ox.ac.uk/MORSE/, 2017.

Eckert, E., von Clarmann, T., Kiefer, M., Stiller, G. P., Lossow, S., Glatthor, N., Degenstein, D. A., Froidevaux, L., GodinBeekmann, S., Leblanc, T., McDermid, S., Pastel, M., Steinbrecht, W., Swart, D. P. J., Walker, K. A., and Bernath, P. F.: Drift-corrected trends and periodic variations in MIPAS IMK/IAA ozone measurements, Atmos. Chem. Phys., 14, 25712589, https://doi.org/10.5194/acp-14-2571-2014, 2014. 
Engelen, R. J., Fowler, L. D., Gleckler, P. J., and Wehner, M. F.: Sampling strategies for the comparison of climate model calculated and satellite observed brightness temperatures, J. Geophys. Res.-Atmos., 105, 9393-9406, https://doi.org/10.1029/1999jd901182, 2000.

Fischer, H., Blom, C., Oelhaf, H., Carli, B., Carlotti, M., Delbouille, L., Ehhalt, D., Flaud, J.-M., Isaksen, I., López-Puertas, M., McElroy, C. T., and Zander, R.: ENVISAT-MIPAS, the Michelson Interferometer for Passive Atmospheric Sounding; An instrument for atmospheric chemistry and Climate Research, in: ESA SP-1229 Readings, edited by: Harris, R. A., European Space Agency, Noordwijk, the Netherlands, 2000.

Fischer, H., Birk, M., Blom, C., Carli, B., Carlotti, M., von Clarmann, T., Delbouille, L., Dudhia, A., Ehhalt, D., Endemann, M., Flaud, J. M., Gessner, R., Kleinert, A., Koopman, R., Langen, J., López-Puertas, M., Mosner, P., Nett, H., Oelhaf, H., Perron, G., Remedios, J., Ridolfi, M., Stiller, G., and Zander, R.: MIPAS: an instrument for atmospheric and climate research, Atmos. Chem. Phys., 8, 2151-2188, https://doi.org/10.5194/acp-8-21512008, 2008.

Froidevaux, L., Anderson, J., Wang, H.-J., Fuller, R. A., Schwartz, M. J., Santee, M. L., Livesey, N. J., Pumphrey, H. C., Bernath, P. F., Russell III, J. M., and McCormick, M. P.: Global OZone Chemistry And Related trace gas Data records for the Stratosphere (GOZCARDS): methodology and sample results with a focus on $\mathrm{HCl}, \mathrm{H}_{2} \mathrm{O}$, and $\mathrm{O}_{3}$, Atmos. Chem. Phys., 15, 1047110507, https://doi.org/10.5194/acp-15-10471-2015, 2015.

Government of Canada: CMAM30 Data, available at: http://climate-modelling.canada.ca/climatemodeldata/cmam/ output/CMAM/CMAM30-SD/index.shtml, last acces: 1 May 2017.

Guan, B., Waliser, D. E., Li, J.-L. F., and da Silva, A.: Evaluating the impact of orbital sampling on satellite-climate model comparisons, J. Geophys. Res.-Atmos., 118, 355-369, https://doi.org/10.1029/2012jd018590, 2013.

Hegglin, M. I. and Shepherd, T. G.: O3-N2O correlations from the Atmospheric Chemistry Experiment: Revisiting a diagnostic of transport and chemistry in the stratosphere, J. Geophys. Res.Atmos., 112, d19301, https://doi.org/10.1029/2006JD008281, 2007.

Hegglin, M. I., Tegtmeier, S., Anderson, J., Froidevaux, L., Fuller, R., Funke, B., Jones, A., Lingenfelser, G., Lumpe, J., Pendlebury, D., Remsberg, E., Rozanov, A., Toohey, M., Urban, J., von Clarmann, T., Walker, K. A., Wang, R., and Weigel, K.: SPARC Data Initiative: Comparison of water vapor climatologies from international satellite limb sounders, J. Geophys. Res.-Atmos., 118, 11824-11846, https://doi.org/10.1002/jgrd.50752, 2013.

Hegglin, M. I., Plummer, D. A., Shepherd, T. G., Scinocca, J. F., Anderson, J., Froidevaux, L., Funke, B., Hurst, D. amd Rozanov, A., Urban, J., von Clarmann, T., Walker, K. A., Wang, H. J., Tegtmeier, S., and Weigel, K.: Vertical structure of stratospheric water vapour trends derived from merged satellite data, Nat. Geosci., 7, 768-776, https://doi.org/10.1038/ngeo2236, 2014.

Hoffmann, L., Spang, R., Kaufmann, M., and Riese, M.: Retrieval of CFC-11 and CFC-12 from Envisat MIPAS observations by means of rapid radiative transfer calculations, Adv. Space Res., 36, 915-921, https://doi.org/10.1016/j.asr.2005.03.112, 2005.

Hubert, D., Lambert, J.-C., Verhoelst, T., Granville, J., Keppens, A., Baray, J.-L., Bourassa, A. E., Cortesi, U., Degenstein, D. A.,
Froidevaux, L., Godin-Beekmann, S., Hoppel, K. W., Johnson, B. J., Kyrölä, E., Leblanc, T., Lichtenberg, G., Marchand, M., McElroy, C. T., Murtagh, D., Nakane, H., Portafaix, T., Querel, R., Russell III, J. M., Salvador, J., Smit, H. G. J., Stebel, K., Steinbrecht, W., Strawbridge, K. B., Stübi, R., Swart, D. P. J., Taha, G., Tarasick, D. W., Thompson, A. M., Urban, J., van Gijsel, J. A. E., Van Malderen, R., von der Gathen, P., Walker, K. A., Wolfram, E., and Zawodny, J. M.: Ground-based assessment of the bias and long-term stability of 14 limb and occultation ozone profile data records, Atmos. Meas. Tech., 9, 2497-2534, https://doi.org/10.5194/amt-9-2497-2016, 2016.

Hurst, D. F., Read, W. G., Vömel, H., Selkirk, H. B., Rosenlof, K. H., Davis, S. M., Hall, E. G., Jordan, A. F., and Oltmans, S. J.: Recent divergences in stratospheric water vapor measurements by frost point hygrometers and the Aura Microwave Limb Sounder, Atmos. Meas. Tech., 9, 4447-4457, https://doi.org/10.5194/amt-9-4447-2016, 2016.

Jin, J. J., Semeniuk, K., Jonsson, A. I., Beagley, S. R., McConnell, J. C., Boone, C. D., Walker, K. A., Bernath, P. F., Rinsland, C. P., Dupuy, E., Ricaud, P., De La Noë, J., Urban, J., and Murtagh, D.: Co-located ACE-FTS and Odin/SMR stratospheric-mesospheric CO 2004 measurements and comparison with a GCM, Geophys. Res. Lett., 32, 115S03, https://doi.org/10.1029/2005GL022433, 2005.

Jin, J. J., Semeniuk, K., Beagley, S. R., Fomichev, V. I., Jonsson, A. I., McConnell, J. C., Urban, J., Murtagh, D., Manney, G. L., Boone, C. D., Bernath, P. F., Walker, K. A., Barret, B., Ricaud, P., and Dupuy, E.: Comparison of CMAM simulations of carbon monoxide $(\mathrm{CO})$, nitrous oxide $\left(\mathrm{N}_{2} \mathrm{O}\right)$, and methane $\left(\mathrm{CH}_{4}\right)$ with observations from Odin/SMR, ACE-FTS, and Aura/MLS, Atmos. Chem. Phys., 9, 3233-3252, https://doi.org/10.5194/acp9-3233-2009, 2009.

Karlsruhe Institute of Technology: IMK/IAA generated MIPAS/Envisat data, available at: https://www.imk-asf.kit.edu/ english/308.php, last access: 1 May 2017.

Kiefer, M., Arnone, E., Dudhia, A., Carlotti, M., Castelli, E., von Clarmann, T., Dinelli, B. M., Kleinert, A., Linden, A., Milz, M., Papandrea, E., and Stiller, G.: Impact of temperature field inhomogeneities on the retrieval of atmospheric species from MIPAS IR limb emission spectra, Atmos. Meas. Tech., 3, 1487-1507, https://doi.org/10.5194/amt-3-1487-2010, 2010.

Livesey, N. J. and Read, W. G.: Direct retrieval of line-of-sight atmospheric structure from limb sounding observations, Geophys. Res. Lett., 27, 891-894, https://doi.org/10.1029/1999GL010964, 2000.

Livesey, N. J., Snyder, W. V., Read, W. G., and Wagner, P. A.: Retrieval algorithms for the EOS Microwave limb sounder (MLS), IEEE Transactions on Geoscience and Remote Sensing, 44, 1144-1155, https://doi.org/10.1109/TGRS.2006.872327, 2006.

Livesey, N. J., Read, W., Wagner, P. A. Froidevaux, L., Lambert, A., Manney, G. L., Millán Valle, L., Pumphrey, H. C., Santee, M. L., Schwartz, M. J., Wang, S., Fuller, R. A., Jarnot, R. F., Knosp, B. W., and Martinez, E.: Version 4.2x Level 2 data quality and description document, JPL D-33509 Rev. C, available at: http: //mls.jpl.nasa.gov (last access: 24 February 2018), 2017.

Luo, M., Beer, R., Jacob, D. J., Logan, J. A., and Rodgers, C. D.: Simulated observation of tropospheric ozone and CO with the Tropospheric Emission Spectrometer (TES) satellite instrument, 
J. Geophys. Res., 107, https://doi.org/10.1029/2001jd000804, 2002.

Manney, G. L., Daffer, W. H., Zawodny, J. M., Bernath, P. F., Hoppel, K. W., Walker, K. A., Knosp, B. W., Boone, C., Remsberg, E. E., Santee, M. L., Harvey, V. L., Pawson, S., Jackson, D. R., Deaver, L., McElroy, C. T., McLinden, C. A., Drummond, J. R., Pumphrey, H. C., Lambert, A., Schwartz, M. J., Froidevaux, L., McLeod, S., Takacs, L. L., Suarez, M. J., Trepte, C. R., Cuddy, D. C., Livesey, N. J., Harwood, R. S., and Waters, J. W.: Solar occultation satellite data and derived meteorological products: Sampling issues and comparisons with Aura Microwave Limb Sounder, J. Geophys. Res.-Atmos., 112, d24S50, https://doi.org/10.1029/2007JD008709, 2007.

Manney, G. L., Hegglin, M. I., Daffer, W. H., Santee, M. L., Ray, E. A., Pawson, S., Schwartz, M. J., Boone, C. D., Froidevaux, L., Livesey, N. J., Read, W. G., and Walker, K. A.: Jet characterization in the upper troposphere/lower stratosphere (UTLS): applications to climatology and transport studies, Atmos. Chem. Phys., 11, 6115-6137, https://doi.org/10.5194/acp11-6115-2011, 2011.

McConnell, A. and North, G. R.: Sampling errors in satellite estimates of tropical rain, J. Geophys. Res., 92, 9567-9570, https://doi.org/10.1029/jd092id08p09567, 1987.

McLandress, C., Plummer, D. A., and Shepherd, T. G.: Technical Note: A simple procedure for removing temporal discontinuities in ERA-Interim upper stratospheric temperatures for use in nudged chemistry-climate model simulations, Atmos. Chem. Phys., 14, 1547-1555, https://doi.org/10.5194/acp14-1547-2014, 2014.

Melo, S. M. L., Blatherwick, R., Davies, J., Fogal, P., de Grandpré, J., McConnell, J., McElroy, C. T., McLandress, C., Murcray, F. J., Olson, J. R., Semeniuk, K., Shepherd, T. G., Strong, K., Tarasick, D., and Williams-Rioux, B. J.: Summertime stratospheric processes at northern mid-latitudes: comparisons between MANTRA balloon measurements and the Canadian Middle Atmosphere Model, Atmos. Chem. Phys., 8, 2057-2071, https://doi.org/10.5194/acp-8-2057-2008, 2008.

Millán, L. F., Livesey, N. J., Santee, M. L., Neu, J. L., Manney, G. L., and Fuller, R. A.: Case studies of the impact of orbital sampling on stratospheric trend detection and derivation of tropical vertical velocities: solar occultation vs. limb emission sounding, Atmos. Chem. Phys., 16, 11521-11534, https://doi.org/10.5194/acp-16-11521-2016, 2016.

Nair, P. J., Godin-Beekmann, S., Froidevaux, L., Flynn, L. E., Zawodny, J. M., Russell III, J. M., Pazmiño, A., Ancellet, G., Steinbrecht, W., Claude, H., Leblanc, T., McDermid, S., van Gijsel, J. A. E., Johnson, B., Thomas, A., Hubert, D., Lambert, J.-C., Nakane, H., and Swart, D. P. J.: Relative drifts and stability of satellite and ground-based stratospheric ozone profiles at NDACC lidar stations, Atmos. Meas. Tech., 5, 1301-1318, https://doi.org/10.5194/amt-5-1301-2012, 2012.

Neu, J. L., Hegglin, M. I., Tegtmeier, S., Bourassa, A., Degenstein, D., Froidevaux, L., Fuller, R., Funke, B., Gille, J., Jones, A., Rozanov, A., Toohey, M., von Clarmann, T., Walker, K. A., and Worden, J. R.: The SPARC Data Initiative: Comparison of upper troposphere/lower stratosphere ozone climatologies from limbviewing instruments and the nadir-viewing Tropospheric Emission Spectrometer, J. Geophys. Res.-Atmos., 119, 6971-6990, https://doi.org/10.1002/2013JD020822, 2014.
Pendlebury, D., Plummer, D., Scinocca, J., Sheese, P., Strong, K., Walker, K., and Degenstein, D.: Comparison of the CMAM30 data set with ACE-FTS and OSIRIS: polar regions, Atmos. Chem. Phys., 15, 12465-12485, https://doi.org/10.5194/acp-1512465-2015, 2015.

Pumphrey, H. C., Filipiak, M. J., Livesey, N. J., Schwartz, M. J., Boone, C., Walker, K. A., Bernath, P., Ricaud, P., Barret, B., Clerbaux, C., Jarnot, R. F., Manney, G. L., and Waters, J. W.: Validation of middle-atmosphere carbon monoxide retrievals from the Microwave Limb Sounder on Aura, J. Geophys. Res.-Atmos., 112, d24S38, https://doi.org/10.1029/2007JD008723, 2007.

Raspollini, P., Arnone, E., Barbara, F., Carli, B., Castelli, E., Ceccherini, S., Dinelli, B. M., Dudhia, A., Kiefer, M., Papandrea, E., and Ridolfi, M.: Comparison of the MIPAS products obtained by four different level 2 processors, Ann. Geophys.-Italy, 56, https://doi.org/10.4401/ag-6338, 2013.

Read, W. G., Lambert, A., Bacmeister, J., Cofield, R. E., Christensen, L. E., Cuddy, D. T., Daffer, W. H., Drouin, B. J., Fetzer, E., Froidevaux, L., Fuller, R., Herman, R., Jarnot, R. F., Jiang, J. H., Jiang, Y. B., Kelly, K., Knosp, B. W., Kovalenko, L. J., Livesey, N. J., Liu, H.-C., Manney, G. L., Pickett, H. M., Pumphrey, H. C., Rosenlof, K. H., Sabounchi, X., Santee, M. L., Schwartz, M. J., Snyder, W. V., Stek, P. C., Su, H., Takacs, L. L., Thurstans, R. P., Vömel, H., Wagner, P. A., Waters, J. W., Webster, C. R., Weinstock, E. M., and Wu, D. L.: Aura Microwave Limb Sounder upper tropospheric and lower stratospheric $\mathrm{H}_{2} \mathrm{O}$ and relative humidity with respect to ice validation, J. Geophys. Res.-Atmos., 112, d24S35, https://doi.org/10.1029/2007JD008752, 2007.

Ridolfi, M., Carli, B., Carlotti, M., von Clarmann, T., Dinelli, B. M., Dudhia, A., Flaud, J.-M., Höpfner, M., Morris, P. E., Raspollini, P., Stiller, G., and Wells, R. J.: Optimized forward model and retrieval scheme for MIPAS near-real-time data processing, Appl. Opt., 39, 1323, https://doi.org/10.1364/ao.39.001323, 2000.

Santee, M. L., Lambert, A., Read, W. G., Livesey, N. J., Cofield, R. E., Cuddy, D. T., Daffer, W. H., Drouin, B. J., Froidevaux, L., Fuller, R. A., Jarnot, R. F., Knosp, B. W., Manney, G. L., Perun, V. S., Snyder, W. V., Stek, P. C., Thurstans, R. P., Wagner, P. A., Waters, J. W., Muscari, G., de Zafra, R. L., Dibb, J. E., Fahey, D. W., Popp, P. J., Marcy, T. P., Jucks, K. W., Toon, G. C., Stachnik, R. A., Bernath, P. F., Boone, C. D., Walker, K. A., Urban, J., and Murtagh, D.: Validation of the Aura Microwave Limb Sounder $\mathrm{HNO}_{3}$ measurements, J. Geophys. Res.-Atmos., 112, d24S40, https://doi.org/10.1029/2007JD008721, 2007.

Schwartz, M. J., Lambert, A., Manney, G. L., Read, W. G., Livesey, N. J., Froidevaux, L., Ao, C. O., Bernath, P. F., Boone, C. D., Cofield, R. E., Daffer, W. H., Drouin, B. J., Fetzer, E. J., Fuller, R. A., Jarnot, R. F., Jiang, J. H., Jiang, Y. B., Knosp, B. W., Krüger, K., Li, J.-L. F., Mlynczak, M. G., Pawson, S., Russell, J. M., Santee, M. L., Snyder, W. V., Stek, P. C., Thurstans, R. P., Tompkins, A. M., Wagner, P. A., Walker, K. A., Waters, J. W., and Wu, D. L.: Validation of the Aura Microwave Limb Sounder temperature and geopotential height measurements, J. Geophys. Res.-Atmos., 113, d15S11, https://doi.org/10.1029/2007JD008783, 2008.

Scinocca, J. F., McFarlane, N. A., Lazare, M., Li, J., and Plummer, D.: Technical Note: The CCCma third generation AGCM and its extension into the middle atmosphere, Atmos. Chem. Phys., 8, 7055-7074, https://doi.org/10.5194/acp-8-7055-2008, 2008. 
Sheese, P. E., Walker, K. A., Boone, C. D., Bernath, P. F., Froidevaux, L., Funke, B., Raspollini, P., and von Clarmann, T.: ACE-FTS ozone, water vapour, nitrous oxide, nitric acid, and carbon monoxide profile comparisons with MIPAS and MLS, J. Quant. Spectrosc. Ra., 186, 63-80, https://doi.org/10.1016/j.jqsrt.2016.06.026, 2017.

Shepherd, T. G., Plummer, D. A., Scinocca, J. F., Hegglin, M. I., Fioletov, V. E., Reader, M. C., Remsberg, E., von Clarmann, T., and Wang, H. J.: Reconciliation of halogen-induced ozone loss with the total-column ozone record, Nat. Geosci., 7, 443-449, https://doi.org/10.1038/ngeo2155, 2014.

Sofieva, V. F., Kalakoski, N., Päivärinta, S.-M., Tamminen, J., Laine, M., and Froidevaux, L.: On sampling uncertainty of satellite ozone profile measurements, Atmos. Meas. Tech., 7, 18911900, https://doi.org/10.5194/amt-7-1891-2014, 2014.

Sohn, B.-J., Schmetz, J., Stuhlmann, R., and Lee, J.-Y.: Dry Bias in Satellite-Derived Clear-Sky Water Vapor and Its Contribution to Longwave Cloud Radiative Forcing, J. Climate, 19, 5570-5580, https://doi.org/10.1175/jcli3948.1, 2006.

Spang, R., Arndt, K., Dudhia, A., Höpfner, M., Hoffmann, L., Hurley, J., Grainger, R. G., Griessbach, S., Poulsen, C., Remedios, J. J., Riese, M., Sembhi, H., Siddans, R., Waterfall, A., and Zehner, C.: Fast cloud parameter retrievals of MIPAS/Envisat, Atmos. Chem. Phys., 12, 7135-7164, https://doi.org/10.5194/acp-127135-2012, 2012.

Stiller, G. P., Kiefer, M., Eckert, E., von Clarmann, T., Kellmann, S., García-Comas, M., Funke, B., Leblanc, T., Fetzer, E., Froidevaux, L., Gomez, M., Hall, E., Hurst, D., Jordan, A., Kämpfer, N., Lambert, A., McDermid, I. S., McGee, T., Miloshevich, L., Nedoluha, G., Read, W., Schneider, M., Schwartz, M., Straub, C., Toon, G., Twigg, L. W., Walker, K., and Whiteman, D. N.: Validation of MIPAS IMK/IAA temperature, water vapor, and ozone profiles with MOHAVE-2009 campaign measurements, Atmos. Meas. Tech., 5, 289-320, https://doi.org/10.5194/amt-5289-2012, 2012.

Tiao, G. C., Reinsel, G. C., Xu, D., Pedrick, J. H., Zhu, X., Miller, A. J., DeLuisi, J. J., Mateer, C. L., and Wuebbles, D. J.: Effects of autocorrelation and temporal sampling schemes on estimates of trend and spatial correlation, J. Geophys. Res.-Atmos., 95, 20507-20517, https://doi.org/10.1029/JD095iD12p20507, 1990.

Toohey, M., Hegglin, M. I., Tegtmeier, S., Anderson, J., Añel, J. A., Bourassa, A., Brohede, S., Degenstein, D., Froidevaux, L., Fuller, R., Funke, B., Gille, J., Jones, A., Kasai, Y., Krüger, K., Kyrölä, E., Neu, J. L., Rozanov, A., Smith, L., Urban, J., von Clarmann, T., Walker, K. A., and Wang, R. H. J.: Characterizing sampling biases in the trace gas climatologies of the SPARC Data Initiative, J. Geophys. Res.-Atmos., 118, 11847 11862, https://doi.org/10.1002/jgrd.50874, 2013. von Clarmann, T., Glatthor, N., Grabowski, U., Höpfner, M., Kellmann, S., Kiefer, M., Linden, A., Tsidu, G. M., Milz, M., Steck, T., Stiller, G. P., Wang, D. Y., Fischer, H., Funke, B., GilLópez, S., and López-Puertas, M.: Retrieval of temperature and tangent altitude pointing from limb emission spectra recorded from space by the Michelson Interferometer for Passive Atmospheric Sounding (MIPAS), J. Geophys. Res.-Atmos., 108, 4736, https://doi.org/10.1029/2003JD003602, 2003.

von Clarmann, T., Höpfner, M., Kellmann, S., Linden, A., Chauhan, S., Funke, B., Grabowski, U., Glatthor, N., Kiefer, M., Schieferdecker, T., Stiller, G. P., and Versick, S.: Retrieval of temperature, $\mathrm{H}_{2} \mathrm{O}, \mathrm{O}_{3}, \mathrm{HNO}_{3}, \mathrm{CH}_{4}, \mathrm{~N}_{2} \mathrm{O}, \mathrm{ClONO}_{2}$ and $\mathrm{ClO}$ from MIPAS reduced resolution nominal mode limb emission measurements, Atmos. Meas. Tech., 2, 159-175, https://doi.org/10.5194/amt-2159-2009, 2009.

Waters, J. W., Froidevaux, L., Harwood, R. S., Jarnot, R. F., Pickett, H. M., Read, W. G., Siegel, P. H., Cofield, R. E., Filipiak, M. J., Flower, D. A., Holden, J. R., Lau, G. K., Livesey, N. J., Manney, G. L., Pumphrey, H. C., Santee, M. L., Wu, D. L., Cuddy, D. T., Lay, R. R., Loo, M. S., Perun, V. S., Schwartz, M. J., Stek, P. C., Thurstans, R. P., Boyles, M. A., Chandra, K. M., Chavez, M. C., Chen, G.-S., Chudasama, B. V., Dodge, R., Fuller, R. A., Girard, M. A., Jiang, J. H., Jiang, Y., Knosp, B. W., LaBelle, R. C., Lam, J. C., Lee, K. A., Miller, D., Oswald, J. E., Patel, N. C., Pukala, D. M., Quintero, O., Scaff, D. M., Snyder, W. V., Tope, M. C., Wagner, P. A., and Walch, M. J.: The Earth observing system microwave limb sounder (EOS MLS) on the aura Satellite, IEEE T. Geosci. Remote, 44, 1075-1092, https://doi.org/10.1109/TGRS.2006.873771, 2006.

Weatherhead, E. C., Reinsel, G. C., Tiao, G. C., Meng, X.-L., Choi, D., Cheang, W.-K., Keller, T., DeLuisi, J., Wuebbles, D. J., Kerr, J. B., Miller, A. J., Oltmans, S. J., and Frederick, J. E.: Factors affecting the detection of trends: Statistical considerations and applications to environmental data, J. Geophys. Res.-Atmos., 103, 17149-17161, https://doi.org/10.1029/98JD00995, 1998.

Yue, Q., Fetzer, E. J., Kahn, B. H., Wong, S., Manipon, G., Guillaume, A., and Wilson, B.: Cloud-State-Dependent Sampling in AIRS Observations Based on CloudSat Cloud Classification, J. Climate, 26, 8357-8377, https://doi.org/10.1175/jcli-d13-00065.1, 2013. 